\title{
Detection of Chlamydophila felis and Feline Herpesvirus Type-1 in non-domestic felids in Brazil
}

\author{
Detecção de Chlamydophila felis e Herpesvirus felino tipo 1 em felídeo não doméstico no \\ Brasil
}

\author{
Meire Christina SEKI ${ }^{1,2}$; Marcos Rogério ANDRE ${ }^{1}$; Adriano de Oliveira Torres CARRASCO ${ }^{2}$; \\ Rosangela Zacarias MACHADO ${ }^{1}$; Aramis Augusto PINTO $^{1}$ \\ ${ }^{1}$ Universidade Estadual Paulista, Faculdade de Ciências Agrárias e Veterinárias, Departamento de Patologia Veterinária, \\ Jaboticabal - SP, Brazil \\ ${ }^{2}$ Universidade Estadual do Centro Oeste, Departamento de Medicina Veterinária, Guarapuava - PR, Brazil
}

\begin{abstract}
Little is known about the occurrence of feline upper respiratory tract disease agents, namely Feline Herpesvirus type 1 (FHV-1) and Chlamydophila felis, and co-infection of these agents with Feline Immunodeficiency virus (FIV) and Feline Leukemia Virus (FeLV) in non-domestic felids in Brazil. Between 2009 and 2010, 72 conjunctival swab and serum samples were collected from eight non-domestic felid species (Leopardus pardalis, Leopardus tigrinus, Panthera leo, Panthera tigris, Puma concolor, Puma yagouaroundi, Oncifelis colocolo, and Panthera onca) maintained in captivity in Brazilian zoos. DNA extracted from conjunctival swabs were used in PCR assays for the detection of Chlamydophila sp, FHV-1, and retrovirus DNA, respectively. Antibodies to FIV and FeLV antigen were detected in non-domestic felid serum samples using a commercial ELISA kit. Antibodies to FIV were found only in five (6.9\%) felids. No sampled non-domestic felid was positive for FeLV antigen detection. One (1.3\%) out of 72 non-domestic felid conjunctival swab samples was positive for Chlamydophila_sp. and Feline Herpesvirus-1 in PCR. This felid was an ocelot and was negative for FIV and FeLV. The results of this survey showed the occurrence of co-infection with $C$. felis and FHV-1 in an ocelot (Leopardus pardalis) in Brazil.
\end{abstract}

Keywords: Chlamydia. Ocelot. PCR. Swab.

\section{Resumo}

Poucos trabalhos descrevem a ocorrência dos agentes do complexo respiratório felino, Herpesvírus Felino tipo 1 (FHV-1) e Chlamydophila felis, e a coinfecção com o vírus da imunodeficiência felina (FIV) e leucemia viral felina (FeLV) em felinos não domésticos no Brasil. Entre 2009 e 2010, 72 amostras de swab de conjuntiva e de soro foram coletados de oito espécies de felinos não domésticos (Leopardus pardalis, Leopardus tigrinus, Panthera leo, Panthera tigris, Puma concolor, Puma yagouaroundi, Oncifelis colocolo, and Panthera onca) mantidos em cativeiro em zoológicos brasileiros. O DNA foi extraído das amostras de swab de conjuntiva para detecção de Chlamydophila sp e FHV-1 pela PCR. Anticorpos para FIV e antígeno para FeLV foram determinados pelo kit comercial de ELISA. Anticorpos para FIV foram detectados em cinco felídeos (6,9\%). Nenhuma amostra foi positiva para a presença de antígeno de FeLV. Um (1,3\%) dos 72 felinos não domésticos apresentou fragmentos de DNA de Chlamydophila sp e FHV-1 pela PCR. Este felino era uma jaguatirica que não apresentou anticorpos para FIV e nem antígeno para FelV. Estes resultados demonstram a ocorrência de coinfecção de C. felis e FHV-1 em uma jaguatirica (Leopardus pardalis) no Brasil.

Palavras-chave: Chlamydia. Jaguatirica. PCR. Swab.

Correspondence to:

Meire Christina Seki

Universidade Estadual do Centro Oeste

Rua Simeão Varela de Sá, 3

CEP 85040-080, Guarapuava, PR, Brazil

email: meireseki@hotmail.com

Received: 20/02/2015

Approved: 06/04/2016

\section{Introduction}

Feline upper respiratory tract disease, caused by both feline herpesvirus type-1 (FHV-1) and Chlamydophila felis, is characterized by nonspecific clinical signs, such as conjunctivitis, nasal and ocular discharge, and sneezing, which often result in misdiagnosis and underestimation of the real 
prevalence of these diseases. Laboratory diagnosis to identify the agent involved in the etiology of upper respiratory tract disease is critical to successful treatment and control (SYKES, 2005).

Chlamydophila felis, formerly Chlamydia psittaci, belongs to the Chlamydiaceae family, which comprises obligate intracellular bacteria whose cell wall resembles those of Gram-negative bacteria (ARTOIS; REMOND, 1994; ADAMS et al., 2010). Clinical signs produced by the infection are influenced by the age of the cat, its immunocompetence, affected tissues and virulence of the inoculum (RAMSEY, 2000). Transmission is thought to occur mainly by direct contact with infectious ocular secretions. Few reports have been published concerning the prevalence of $C$. felis among non-domestic felids, mainly in Brazil. Such reports include a study that found seroprevalence of 27\% among wild cats in Europe (MILLÁN; RODRÍGUEZ, 2009), and the detection of $C$. felis in tissues (liver and kidney) of a fishing cat (Felis viverrina) in the Netherlands using the Direct Immunofluorescence Assay (KIK et al., 1997).

FHV-1, an Alpha-herpesvirus member of the family Herpesviridae, shows biological behavior similar to other herpesviruses, causing primary infection followed by latent infection without apparent clinical signs. During latency, the virus incubates in sensory ganglia, where no viral replication occurs (MAGGS, 2005). When reactivation takes place, susceptible animals may be infected by contact with agents excreted in nasal and ocular secretions (STILES, 2000). Although seropositivity to this agent has been reported among captive and free-ranging wild felids in Brazil, Europe, Asia, North America, and Africa, active virus detection has been infrequently observed in these animals (ARTOIS; REMOND, 1994; DANIELS et al., 1999; LEUTENEGGER et al., 1999; MURRAY et al, 1999, OSTROWSKI et al., 2003; BATISTA et al.,2005; FILONI et al., 2006; FILONI et al., 2011).
The co-infection of immunosuppressive retroviruses (such as Feline Immunodeficiency Virus - FIV- and Feline Leukemia Virus - FeLV) with C. felis and FHV1 may increase the severity of clinical signs and excretion of the upper respiratory tract disease agent (REUBEL et al., 1992). Retroviral infections have been detected among free-ranging and captive nondomestic felids in Brazil by molecular and serological techniques (FILONI et al., 2003; BATISTA et al., 2005; FILONI et al., 2006; GUIMARÃES et al., 2009; FILONI et al., 2011).

The present study describes the occurrence of $C$. felis, FHV-1, FeLV and FIV infections in non-domestic felids in Brazil.

\section{Materials and Methods}

\section{Sampling population and assays}

From 2009 to 2010, 72 blood samples and conjunctival swabs were collected from non-domestic felid species, namely Leopardus pardalis (ocelot, $\mathrm{n}=$ 14), Leopardus tigrinus (little spotted cat, $\mathrm{n}=24$ ), Panthera leo (lion, $\mathrm{n}=5$ ), Panthera tigris (tiger, $\mathrm{n}=2$ ), Puma concolor (puma, $\mathrm{n}=6$ ), Puma yagouaroundi (jaguarondi, $\mathrm{n}=16$ ), Oncifelis colocolo (pampas cat, $\mathrm{n}$ $=1$ ), Panthera onca (jaguar, $n=3$ ), which were kept in captivity in ten Brazilian Zoos in different sites. Animals were immobilized using a combination of ketamine $(10 \mathrm{mg} / \mathrm{kg})$ and xylazine $(1 \mathrm{mg} / \mathrm{kg})$ (FILONI et al., 2003). Blood samples were collected by venipuncture. Serum samples were obtained after incubation at room temperature until clot formation, followed by a centrifugation. Sera were placed in 1.5 $\mathrm{mL}$ polypropylene tubes and stored at $-18^{\circ} \mathrm{C}$. A dry, sterile cotton swab that was moistened with tears or exudate was used to firmly swab the conjunctival sacs of both eyes. Swabs specimens were stored at $-20^{\circ} \mathrm{C}$ until they were used in the PCR assays (SYKES et al., 1997) (Table 1). 
Table 1 - Number, species and zoo location of sampled non-domestic felids

\begin{tabular}{|c|c|c|}
\hline $\begin{array}{c}\text { Species } \\
\text { (Common name) }\end{array}$ & Location (n) of swab samples & $\begin{array}{c}\text { Total number of } \\
\text { samples }\end{array}$ \\
\hline $\begin{array}{l}\text { Leopardus pardalis } \\
\text { (ocelot) }\end{array}$ & Am (2), IS (2), So (1), Bau (3), Ita (2), Pir (4) & 14 \\
\hline $\begin{array}{l}\text { Leopardus tigrinus } \\
\text { (little spotted cat) }\end{array}$ & IS (2), So (14), SC (1), Ita (1), Pir (3), Cat (1), NO (2) & 24 \\
\hline $\begin{array}{l}\text { Panthera onca } \\
\text { (jaguar) }\end{array}$ & Am (1), So (1), Bau (1), & 3 \\
\hline $\begin{array}{l}\text { Puma concolor } \\
\text { (puma) }\end{array}$ & $\operatorname{Rp}(1), \operatorname{Am}(2)$, So (1), Cat (2) & 6 \\
\hline $\begin{array}{c}\text { Puma yagouaroundi } \\
\text { (jaguarondi) }\end{array}$ & IS (4), So (3), SC(2), Bau (3), Ita (3), Pir (1) & 16 \\
\hline $\begin{array}{l}\text { Oncifelis colocolo } \\
\text { (pampas cat) }\end{array}$ & So(1) & 1 \\
\hline $\begin{array}{l}\text { Panthera tigris* } \\
\text { (tiger) }\end{array}$ & So (1), Ita (1) & 2 \\
\hline $\begin{array}{l}\text { Panthera leo* } \\
\text { (lion) }\end{array}$ & Am (1), So (1), Bau (3) & 5 \\
\hline
\end{tabular}

Samples were collected from institutions in different cities in the state of São Paulo, such as Americana $\quad\left(22^{\circ} 44^{\prime} 21^{\prime \prime} \mathrm{S}, \quad 47^{\circ} 19^{\prime} 53^{\prime \prime} \mathrm{W}\right)$, Bauru

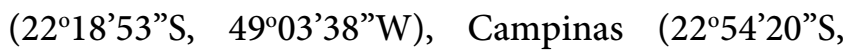

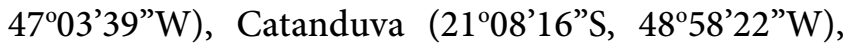
Ilha Solteira $\left(20^{\circ} 25^{\prime} 58^{\prime \prime} \mathrm{S}, \quad 51^{\circ} 20^{\prime} 33^{\prime \prime} \mathrm{W}\right)$, Itatiba

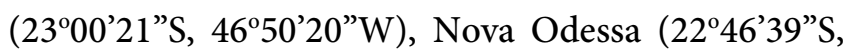
$\left.47^{\circ} 17^{\prime} 45^{\prime \prime} \mathrm{W}\right)$, Piracicaba (22 $\left.43^{\prime} 31^{\prime \prime} \mathrm{S}, 47^{\circ} 38^{\prime} 57^{\prime \prime} \mathrm{W}\right)$, Ribeirão Preto $\left(21^{\circ} 10^{\prime} 39^{\prime \prime S}, 47^{\circ} 48^{\prime} 37^{\prime \prime} \mathrm{W}\right)$, São Carlos

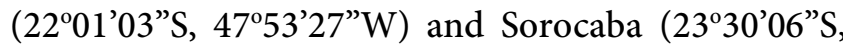
$\left.47^{\circ} 27^{\prime} 29^{\prime \prime} \mathrm{W}\right)$ (Table 1).

All procedures were performed with permission from the Brazilian Institute of Environment and Renewable Natural Resources (IBAMA) (license number 20012-1/2009), and following the Ethical Principles in Animal Research adopted by the Brazilian College of Animal Experimentation. The study was approved by the Ethics Committee of the Faculty of Agricultural and Veterinary Sciences, UNESP Jaboticabal.

\section{Serum assay}

Commercially available immunoassay Snap ${ }^{\text {tw }}$ Combo FeLV antigen/FIV antibody test kit (IDEXX Laboratories Inc., Westbrook, ME, USA) was used in the detection of FeLV antigen and antibodies against FIV, according to the manufacturer's recommendations.

\section{Polymerase Chain Reaction}

DNA extraction. Conjunctival swab samples were submitted to vortex for $2 \mathrm{~min}$ and then centrifuged at $20,000 \mathrm{x} g$ for $30 \mathrm{~min}$ at $4^{\circ} \mathrm{C}$ (RASO et al., 2006). DNA was extracted from pellets using Genomic DNA from Tissue kit (Macherey-Nagel GmbH \& Co., Düren, Düren, German) according to the manufacturer's instructions.

PCR amplification and sequencing. Each sample of DNA extracted from conjunctival samples was used in PCR reactions for Chlamydophila sp. and FHV-1. 
Five microliters of DNA template were used in $25 \mu \mathrm{L}$ reaction mixtures containing 10X PCR buffer, $1.0 \mathrm{mM}$ $\mathrm{MgCl} 2, \quad 0.2 \mathrm{mM}$ deoxynucleotide triphosphate (dNTPs) mixture, $1.5 \mathrm{U}$ Taq DNA Polymerase (Invitrogen, Carlsbad, CA, USA), and $1 \mu \mathrm{M}$ of primers.

PCR reactions for Chlamydophila sp. were performed using primers oligo420 (5'CAGGATATCTTGTCTGGCTTTAA-3') and oligo422 (5'-GCAAGGATCGCAAGGATC-3'), which target the conserved region of the chlamydial major outer membrane protein gene (MOMP) and amplify a 260 base pair (bp) DNA fragment (BUXTON et al., 1996). PCR cycling conditions were $10 \mathrm{~min}$ at $94^{\circ} \mathrm{C} ; 34$ cycles at $94^{\circ} \mathrm{C}$ for $1 \mathrm{~min}, 54^{\circ} \mathrm{C}$ for $1 \mathrm{~min}$, and $72^{\circ} \mathrm{C}$ for $1 \mathrm{~min}$; and a final extension at $72^{\circ} \mathrm{C}$ for $4 \mathrm{~min}$. Positive $(C$. felis vaccine - Fel-O-Vax LVK-IV'; Fort Dodge, Fort Dodge, IA, USA), negative (cat swab sample negative for Chlamydophila sp. ) and no-template (autoclaved ultrapure water, Promega Corp. , Fitchburg, WI, USA) controls were routinely included in each PCR reaction (SEKI et al., 2010).

PCR for FHV-1 detection was performed using primers 5'-GACGTGGTGAATTATCAGC-3' and 5'CAACTAGATTTCCACCAGGA-3' based on the gene that encodes FHV-1 thymidine kinase and amplifies a 287bp DNA fragment (SYKES et al., 1997). PCR cycling conditions were $5 \mathrm{~min}$ at $95^{\circ} \mathrm{C} ; 35$ cycles at $90^{\circ} \mathrm{C}$ for $1 \mathrm{~min}, 56^{\circ} \mathrm{C}$ for $1 \mathrm{~min}$, and $72^{\circ} \mathrm{C}$ for $1 \mathrm{~min}$; and a final extension at $72^{\circ} \mathrm{C}$ for $4 \mathrm{~min}$. Positive (Herpesvirus vaccine Fel-O-Vax LVK-IV', Fort Dodge, Iowa, USA), negative (cat swab sample negative for FHV-1) and no-template (autoclaved ultrapure water, Promega Corp., Fitchburg, WI, USA) controls were routinely included in each $\mathrm{PCR}$ reaction.

Positive amplicons were purified from agarose gels using Silica Bead DNA Gel Extraction Kit (Glen Burnie, $\mathrm{MD}$, USA) according to the manufacturer's recommendations. Purified amplicons were submitted to sequence confirmation in an automatic sequencer (ABI Prism 310 Genetic Analyzer - Applied Biosystems/Life
Technologies Corporation, Carlsbad, CA, USA). Consensus sequences were obtained by means of the analysis of sense and antisense sequences using the CAP3 program ${ }^{1}$. Comparisons with GenBank sequences were performed using the basic local alignment search tool (BLAST) (ALTSCHUL et al., 1990).

\section{Results}

Chlamydophilasp. DNA was detected in one (1.4\%) out of 72 non-domestic felid conjunctival swab samples. The same animal (an ocelot from Sorocaba zoo) was also positive for FHV-1 PCR. Chlamydophila sp. and FHV-1 DNA sequences were deposited in GenBank database under accession numbers JQ677600 and JQ677601, respectively. Sequencing showed 95\% similarity with FHV-1 (closest GenBank similarity: accession numbers FJ478159 and M26660), and 92\% similarity with $C$. felis (closest GenBank similarity: accession number AP006861).

All sampled animals were negative for antigen to FeLV. Five felids (6.9\%) showed antibodies to FIV (three lions from the Bauru zoo, one lion from the Sorocaba zoo and one ocelot from the Itatiba zoo (Table 1). The ocelot positive for Chlamydophila felis and HVF-1 in PCR was negative for FIV and FeLV.

\section{Discussion}

Active infection to $C$. felis was confirmed by PCR and sequencing in just one ocelot. To the authors' knowledge, this study reports the first molecular detection of $C$. felis in a non-domestic felid species. Previously, direct diagnosis of $C$. felis has only been performed by Direct Immunofluorescence Assay in a fishing cat (KIK et al., 1997). In Brazil, $C$. felis was detected in domestic cats by PCR in the northeastern region of the state of São Paulo (SEKI et al., 2010) and in Osasco, also in the state of São Paulo (GONSALES et al., 2013).

\footnotetext{
${ }^{1}$ http://mobyle.pasteur.fr/cgi-bin/MobylePortal/portal.py
} 
The ocelot positive for $C$. felis PCR also tested positive for FHV-1 PCR. In Brazil, low percentages of seropositivity and low antibody titers were found among non-domestic felids maintained in captivity, suggesting that FHV-1 does not circulate extensively among these animals (BATISTA et al., 2005). Antibodies to FHV-1 have also been detected among neotropical free-ranging wild felids in Brazil (FILONI et al., 2006). Recently, FHV-1 seroprevalence of 19\% $(12 / 63)$ was found in non-vaccinated captive nondomestic felids in Brazil (FILONI et al., 2011). The observed failure to isolate FHV in felines is not surprising, since this virus is maintained as latent infection followed by intermittent shedding in nasal and ocular secretions (GASKELL; DAWSON, 1995).

The contact between domestic and non-domestic felids is the most feasible way of FHV-1 and C. felis transmission, mainly among captive felids. Animals that live in groups may be more susceptible to close contact with infected animals; thus, the possibility of pathogen transmission may be higher. Non-domestic felids with solitary habits, like those sampled in our study, are less frequently in contact with many different animals, which may limit the possibility of pathogen transmission.

The lack of felids positive for FeLV (antigen or DNA) corroborated the results of a previous study that sampled captive neotropical small felids from Brazil, suggesting that retrovirus infection is not frequently found in these felid populations (FILONI et al., 2003). On the other hand, FeLV proviral DNA was detected in one ocelot and one little spotted cat from Itaipu Binational Wildlife Research Center, in southern Brazil (GUIMARÃES et al., 2009). Antibodies to FeLV were detected in two pumas among 18 free-ranging wild felids sampled in different geographic regions of Brazil (FILONI et al., 2006). Recently, FeLV seroprevalence of $2 \%(3 / 145)$ was detected in captive non-domestic felids in Brazil; additionally, FeLV antigen and DNA were detected in two other ocelots in the same study (FILONI et al., 2011). Reports of FeLV infection in non-domestic felids are rare and predominantly found in captive animals (BRIGGS; OTT, 1986; CITINO, 1986). FeLV antigenemia was detected in non-domestic felids in Scotland, France, Switzerland, and Germany (MCORIST et al., 1991; ARTOIS; REMOND, 1994; DANIELS et al., 1999; LEUTENEGGER et al., 1999; FROMONT et al., 2000; MILLÁN; RODRÍGUEZ, 2009). FeLV is transmitted rapidly among young domestic felids via infected body fluids, such as during fighting or mating (MCORIST et al., 1991). These sort of interactions are probably uncommon among captive non-domestic felids and between wild and domestic cats in Brazil. Furthermore, captivity lifestyle decreases the risk of acquiring the virus in fighting. FeLV is more likely to appear as a sustained infection among some wild felid populations rather than as a result of occasional infection acquired from domestic cats (MCORIST et al., 1991).

In this study, antibodies to FIV were detected in six lions and one ocelot. In a previous study conducted in Brazil, antibodies to FIV were not found in captive neotropical small felids (FILONI et al., 2003). Also, this agent was frequently detected in blood samples from wild felids in Europe and Africa (MCORIST et al., 1991; OLMSTED et al., 1992; SPENCER et al., 1992; BROWN et al., 1993; DANIELS et al., 1999; LEUTENEGGER et al., 1999; FROMONT et al., 2000).

Furthermore, several studies have reported the absence of seropositivity to FIV among non-domestic felids around the world (OLMSTED et al., 1992; SPENCER et al., 1992; BROWN et al., 1993; ROELKE et al., 1993, PAUL-MURPHY et al., 1994; OSOFSKY et al., 1996; MUNSON et al., 2004; MILLÁN; RODRÍGUEZ, 2009; THALWITZER et al., 2010). Among 18 free-ranging Brazilian non-domestic felids, antibodies to FIV were detected in only one puma from the Pantanal biome (FILONI et al., 2006). Recently, FIV seroprevalence of $4.8 \%$ was detected among 145 non-domestic captive felids in Brazil (FILONI et al., 2011). The most common FIV transmission route is biting; therefore, a relative lack of social contact between non-domestic felids maintained in captivity may explain the absence 
or low occurrence of FIV infection (DANIELS et al., 1999).

According to the literature, co-infection of immunosuppressive retroviruses (such as Feline Immunodeficiency Virus and Feline Leukemia Virus) with $C$. felis and HVF-1 may increase the severity of clinical signs and excretion of the upper respiratory tract disease agent (REUBEL et al., 1992). However, the ocelot positive for C.felis and HVF-1 by PCR was negative for FIV and FeLV.

Six of the seven existing species of Brazilian nondomestic felids, including ocelots (Leopardus pardalis), little spotted cats (Leopardus tigrinus), margays (Leopardus wiedii), pampas cats (Oncifelis colocolo), jaguars (Panthera onca), and pumas (Puma concolor) are endangered (www.ibama.gov. br). Knowledge of the occurrence of these agents in captive non-domestic felids may contribute to future ecological investigations regarding the epidemiology of these pathogens among free-ranging non-domestic felids and domestic cats in Brazil.

\section{References}

ADAMS, H.; VUUREN, M. V.; KANIA, S.; BOSMAN, A. M.; KEEN, D.; NEW JUNIOR, J. C.; KENNEDY, M. Sensitivity and specificity of a nested polymerase chain reaction for detection of lentivirus infection in lions (Panthera leo). Journal of Zoo and Wildlife Medicine, v. 41, n. 4, p. 608615, 2010. doi: http://dx.doi.org/10.1638/2009-0137.1.

ALTSCHUL, S. F.; GISH, W.; MILLER, W.; MYERS, E. W.; LIPMAN, D. J. Basic local alignment search tool. Journal of Molecular Biology, v. 215, n. 3, p. 403-410, 1990. doi: http://dx.doi.org/10.1016/S0022-2836(05)80360-2.

ARTOIS, M.; REMOND, M. Viral diseases as a threat to freeliving wild cats (Felis silvestris) in continental Europe. Veterinary Record, v. 134, n. 25, p. 651-652, 1994. doi: http://dx.doi.org/10.1136/vr.134.25.651.

BATISTA, H. B. C. R.; VICENTINI, F. K.; FRANCO, A. C.; SPILKI, F. R.; SILVA, J. C. R.; ADANIA, C. H.; ROEHE, P. M. Neutralizing antibodies against feline herpesvirus type 1

\section{Conclusion}

The present paper describes the occurrence of $C$. felis and FHV-1 in non-domestic felid species maintained in captivity in Brazil. Multiple diagnostic protocols regarding the diagnosis of these infectious agents should be considered prior to translocating animals between zoos, reintroducing captive animals to the wild, or relocating them from densely to thinly populated areas.

\section{Acknowledgements}

The authors would like to thank Fundação de Amparo à Pesquisa do Estado de São Paulo (FAPESP) for financial support (Process number 2009/17513-5) and to Instituto Brasileiro do Meio Ambiente e dos Recursos Naturais Renováveis (IBAMA) for the license to collect and pack blood and conjunctival swab samples from non-domestic captive felids. The authors are also very thankful to the Americana, Bauru, Catanduva, Ilha Solteira, Itatiba, Nova Odessa, Piracicaba, Ribeirão Preto, São Carlos, and Sorocaba Zoos.

in captive wild felids of Brazil. Journal of Zoo and Wildlife Medicine, v. 36, n. 3, p. 447-450, 2005. doi: http://dx.doi.org/10.1638/04-060.1.

BRIGGS, M. B.; OTT, R. L. Feline leukemia virus infection in a captive cheetah and the clinical and antibody response of six captive cheetahs to vaccination with a subunit feline leukemia virus vaccine. Journal of the American Veterinary Medical Association, v. 189, n. 9, p. 1197-1199, 1986.

BROWN, E. W.; MITHTHAPALA, S.; O'BRIEN, S. J. Prevalence of exposure to feline immunodeficiency virus in exotic felid species. Journal of Zoo and Wildlife Medicine, v. 24, n. 3, p. 357-364, 1993.

BUXTON, D.; RAE, A. G.; MALEY, S. W.; THOMSON, K. M.; LIVINGSTONE, M.; JONES, G. E.; HERRING, A. J. Pathogenesis of Chlamydia psittaci infection in sheep: detection of the organism in a serial study of the lymph node. 
Journal of Comparative Pathology, v. 114, n. 3, p. 221-230, 1996. doi: http://dx.doi.org/10.1016/S0021-9975(96)80044-2.

CITINO, S. B. Transient FeLV viraemia in a clouded leopard. Journal of Zoo Animal Medicine, v. 17, n. 1, p. 5-7, 1986. doi: http://dx.doi.org/10.2307/20094780.

DANIELS, M. J.; GOLDER, M. C.; JARRET, O.; MACDONALD, D. W. Feline viruses in wildcats from Scotland. Journal of Wildlife Diseases, v. 35, n. 1, p. 121124, 1999. doi: http://dx.doi.org/10.7589/0090-3558-35.1.121.

FILONI, C.; ADANIA, C. H.; DURIGON, E. L.; CATÃO-DIAS, J. L. Serosurvey of feline leucemia virus and lentivirus in captive small neotropical felids in São Paulo state, Brazil. Journal of Zoo and Wildlife Medicine, v. 34, n. 1, p. 6568 2003. doi: http://dx.doi.org/10.1638/10427260(2003)34[0065:SFFLVA]2.0.CO;2.

FILONI, C.; CATÃO-DIAS, J. L.; BAY, G.; DURIGON, E. L.; JORGE, R. S. P.; LUTZ, H.; HOFMANN-LEHMANN, R. First evidence of feline herpesvirus, calicivirus, parvovirus, and Ehrlichia_exposure in Brazilian free-ranging felids. Journal of Wildlife Diseases, v. 42, n. 2, p. 470-477, 2006. doi: http://dx.doi.org/10.7589/0090-3558-42.2.470.

FILONI, C.; CATÃO-DIAS, J. L.; CATTORI, V.; WILLI, B.; MELI, M. L.; CORRÊA, S. H. R.; MARQUES, M. C.; ADANIA, C. H.; SILVA, J. C. R.; MARVULO, M. F. V.; NETO, J. S. F.; DURIGON, E. L.; CARVALHO, V. M.; COUTINHO, S. D.; LUTZ, H.; HOFMANN-LEHMANN, R. Surveillance using serological and molecular methods for the detection of infectious agents in captive Brazilian neotropic and exotic felids. Journal of Veterinary Diagnostic Investigation, v. 24, n. 1, p. 166-173, 2011. doi: http://dx.doi.org/10.1177/1040638711407684.

FROMONT, E.; PONTIER, D.; SAGER, A.; JOUQUELET, E.; ARTOIS, M.; LÉGER, F.; STAHL, P.; BOURGUEMESTRE, F. Prevalence and pathogenicity of retrovirus in wildcats in France. Veterinary Record, v. 146, n. 11, p. 317-319, 2000. doi: http://dx.doi.org/10.1136/vr.146.11.317.

GASKELL, R. M.; DAWSON, S. Viral induced upper respiratory tract disease. In: CHANDLER, E. A.; GASKELL, C. J.; GASKELL, R. M. Feline medicine and therapeutics. $2^{\text {nd }}$ ed. Oxford: Blackwell Scientific Publications, 1995. p. 453-472.

GONSALES, F. F.; BRANDÃO, P. E.; MELVILLE, P. A.; HORA, A. S.; ZUNIGA, E.; SAIDENBERG, A.; SALABERRY, S.; BENITES, N. R. Ocorrência de Chlamydophila felis em um gatil na região de Osasco, São Paulo. Brazilian Journal of Veterinary Research and Animal Science, v. 50, n. 5, p.
379-393, 2013. doi: http://dx.doi.org/10.11606/issn.23183659.v50i5p379-383.

GUIMARÃES, A. M.; BRANDÃO, P. E.; MORAES, W.; CUBAS, Z. S.; SANTOS, L. C.; VILLARREAL, L. Y.; ROBES, R. R.; COELHO, F. M.; RESENDE, M.; SANTOS, R. C.; OLIVEIRA, R. C.; YAMAGUTI, M.; MARQUES, L. M.; NETO, R. L.; BUZINHANI, M.; MARQUES, R.; MESSICK, J. B.; BIONDO, A. W.; TIMENETSKY, J. Survey of feline leukemia virus and feline coronaviruses in captive neotropical wild felids from Southern Brazil. Journal of Zoo and Wildlife Medicine, v. 40, n. 2, p. 360-364, 2009. doi: http://dx.doi.org/10.1638/2008-0067.1.

KIK, M. J. L.; VAN DER HAGE, M. H.; GREYDANUS-VAN DER PUTEEN, W. M. Chlamydiosis in a fishing cat (Felis viverrina). Journal of Zoo and Wildlife Medicine, v. 28, n. 2, p. 212-214, 1997.

LARA, V. M.; TANIWAKI, S. A.; ARAÚJO JÚNIOR, J. P. Occurrence of feline immunodeficiency virus infection in cats. Ciência Rural, v. 38, n. 8, p. 2245-2249, 2008. doi: http://dx.doi.org/10.1590/S0103-84782008000800024.

LEUTENEGGER, C. M.; HOFFMAN-LEHMANN, R.; RIOLS, C.; LIBEREK, M.; WOREL, G.; LUPS, P.; FEHR, D.; HARTMANN, M.; WEILENMANN, P.; LUTZ, H. J. Viral infections in free-living populations of the European wildcat. Journal of Wildlife Diseases, v. 35, n. 4, p. 678-686, 1999. doi: http://dx.doi.org/10.7589/0090-3558-35.4.678.

MAGGS, D. J. Update on pathogenesis, diagnosis, and treatment of feline herpesvirus type 1. Clinical Techniques in Small Animal Practice, v. 20, n. 2, p. 94-101, 2005. doi: http://dx.doi.org/10.1053/j.ctsap. 2004.12.013.

MCORIST, S.; BOID, R.; JONES, T. W.; EASTERBEE, N.; HUBBARD, A. L.; JARRET, O. Some viral and protozool diseases in the European wildcat (Felis silvestris). Journal of Wildlife Diseases, v. 27, n. 4, p. 693-696, 1991. doi: http://dx.doi.org/10.7589/0090-3558-27.4.693.

MILLÁN, J.; RODRÍGUEZ, A. A serological survey of common feline pathogens in free-living European wildcats (Felis silvestris) in central Spain. European Journal of Wildlife Research, v. 55, n. 3, p. 285-291, 2009. doi: http://dx.doi.org/10.1007/s10344-008-0246-z.

MUNSON, L.; MARKER, L.; DUBOVI, E.; SPENCER, J. A.; EVERMANN, J. F.; O'BRIEN, J. S. Serosurvey of viral infections in free-ranging Namibian Cheetahs (Acinonyx jubatus). Journal of Wildlife Diseases, v. 40, n. 1, p. 23-31, 2004. doi: http://dx.doi.org/10.7589/0090-3558-40.1.23.

Braz. J. Vet. Res. Anim. Sci., São Paulo, v. 53, n. 2, p. 169-176, 2016 
MURRAY, D. L.; KAPKE, C. A.; EVERMANN, J. F.; FULLER, T. K. Infectious disease and the conservation of free-ranging large carnivores. Animal Conservation, v. 2, n. 4, p. 241-254, 1999. doi: http://dx.doi.org/10.1111/j.1469-1795.1999.tb00070.x.

OLMSTED, R. A.; LANGLEY, R.; ROELKE, M. E.; GOEKEN, R. M.; ADGER-JOHNSON, D.; GOFF, J. P.; ALBERT, J. P.; PACKER, C.; LAURENSON, K. M.; CARO, T. M; SCHEEPERS, L.;WILDT, D. E.; BUSH, M.; MARTENSON, J. S.; O'BRIEN, S. J. Worldwide prevalence of lentivirus infection in wild feline species: epidemiologic and phylogenetic aspects. Journal of Virology, v. 66, n. 10, p. 6008-6018, 1992.

OSOFSKY, S. A.; HIRSCH, K. J.; ZUCKERMAN, E. E.; HARDY, W. D. Feline lentivirus and feline oncovirus status of free-ranging lions (Panthera leo), leopards (Panthera pardus), and cheetahs (Acinonyx jubatus) in Botswana: a regional perspective. Journal of Zoo and Wildlife Medicine, v. 27, n. 4, p. 453-467, 1996.

OSTROWSKI, S.; VAN VUUREN, M.; LENAIN, D. M.; DURAND, A. A serologic survey of wild felids from Central West Saudi Arabia. Journal of Wildlife Diseases, v. 39, n. 3, p. 696-701, 2003. doi: http://dx.doi.org/10.7589/0090-355839.3.696.

PAUL-MURPHY, J.; WORK, T.; HUNTER, D.; MCFIE, E; FJELLINE, D. Serologic survey and serum biochemical reference ranges of the free-ranging mountain lions (Felis concolor) in California. Journal of Wildlife Diseases, v. 30, n. 2, p. 205-215, 1994. doi: http://dx.doi.org/10.7589/00903558-30.2.205.

RAMSEY, D. T. Feline Chlamydia and Calicivirus infections. The Veterinary Clinics of North America: Small Animal Practice, v. 30, n. 5, p. 1015-1028, 2000. doi: http://dx.doi.org/10.1016/S0195-5616(00)05004-X.

RASO, T. F.; SEIXAS, G. H. F.; GUEDES, N. M. R; PINTO, A. A. Chlamydophila psittaci in free-living Blue-fronted Amazon parrots (Amazon aestiva) and Hyacinth macaws (Anadorhynchus hyacnthinus) in the Pantanal of Mato Grosso do Sul, Brazil. Veterinary Microbiology, v. 117, n. 24,p.235-241, 2006. doi:http://dx.doi.org/10.1016/j.vetmic.2006.06.025.

REUBEL, G. H.; GEORGE, J. W.; BARLOUGH, J. E; HIGGINS, J.; GRANT, C. K.; PEDERSEN, N. C. Interaction of acute feline herpesvirus-1 and chronic feline immunodeficiency virus infections in experimentally infected specific pathogen free cats. Veterinary Immunology and Immunopathology, v. 35, n. 1-2, p. 95-119, 1992. doi: http://dx.doi.org/10.1016/0165-2427(92)90124-9.

ROELKE, M. E.; FORRESTER, D. J.; JACOBSON, E. R.; KOLLIAS, G. V.; SCOTT, F. W.; BARR, M. C.; EVERMANN, J. F.; PIRTLE, E. C. Seroprevalence of infectious disease agents in free-ranging Florida panthers (Felis concolor coryi). Journal of Wildlife Diseases, v. 29, n. 1, p. 36-49, 1993. doi: http://dx.doi.org/10.7589/0090-3558-29.1.36.

SEKI, M. C.; CARRASCO, A. O. T.; MINEO, T. W. P.; RASO, T. F.; PINTO, A. A. DNA detection and antibody evaluation against Chlamydophila felis in domestic cats from Northeast of the state of São Paulo, Brazil. Virus Reviews and Research, v. 15, n. 2, p. 28-42. 2010. doi: http://dx.doi.org/10.17525/vrr.v15i2.42.

SPENCER, J. A.; VAN DIJK, A. A.; HORZINEK, M. C.; EGBERINK, H. F.; BENGIS, R. G.; KEET, D. F.; MORIKAWA, S.; BISHOP, D. H. L. Incidence of feline immunodeficiency virus reactive antibodies in free-ranging lions of the Kruger National Park and the Etosha National Park in Southern Africa detected by recombinant FIV p24 antigen. Journal of Veterinary Research, v. 59, n. 4, p. 315-322, 1992.

STILES, J. Feline herpesvirus. The Veterinary Clinics of North America: Small Animal Practice, v. 30, n. 5, p. 10011004, 2000. doi: http://dx.doi.org/10.1016/S0195-5616(00)05003-8.

SYKES, J. E. Feline chlamydiosis. Clinical Techniques in Small Animal Practice, v. 20, n. 2, p. 129-134, 2005. doi: http://dx.doi.org/10.1053/j.ctsap. 2004.12.018.

SYKES, J. E.; BROWNING, G. F.; ANDERSON, G.; STUDDERT, V. P.; SMITH, H. V. Differential sensitivity of culture and the polymerase chain reaction for detection of feline herpesvirus 1 in vaccinated and unvaccinated cats. Archives of Virology, v. 142, n. 1, p. 65-74, 1997. doi: http://dx.doi.org/10.1007/s007050050059.

THALWITZER, S.; WACHTER, B.; ROBERT, N.; WIBBELT, G.; MULLER, T.; LONZER, J.; MELI, M. L.; BAY, G.; HEFER, H.; LUTZ, H. Seroprevalences to viral pathogens in freeranging and captive cheetahs (Acinonyx jubatus) on Namibian farmland. Clinical and Vaccine Immunology, v. 17, n. 2, p. 232-238, 2010. doi:http://dx.doi.org/10.1128/CVI.0034509. 